\title{
Politics, Prohibitions and the Lost Public Perspective: A COMMENT ON Bill C-56: THE ASSISTED HUMAN REPRODUCTION ACT
}

\author{
TIMOTHY CAULFIELD
}

\section{INTRODUCTION}

On 9 May 2002, the federal government released its long-awaited Bill on reproductive technologies. As expected, Bill C-56, An Act respecting assisted human reproduction,' has generated a significant amount of controversy. There are those who feel it is too restrictive, thus inappropriately impeding scientific research. Others have suggested that the government needs to go further by limiting when embryonic stem (ES) cell research can occur.

The Bill covers a wide range of issues, from the banning of commercial surrogacy ${ }^{2}$ to the regulation of most activities related to assisted reproduction. ${ }^{3}$ However, the provisions addressing human cloning and stem cell research have attracted the most attention. Given the degree of social controversy surrounding the legislation and its long and troubled history, ${ }^{4}$ the Bill was destined to be a compromise - neither completely satisfying those, myself included, who had hoped for a more nuanced approach to the

Canada Research Chair in Health Law and Policy, Associate Professor, Faculty of Law and Faculty of Medicine and Dentistry, Research Director, Health Law Institute, University of Alberta. I would like to thank Abdallah Daar, Bartha Maria Knoppers, Peter Singer, Francoise Baylis, and the HLI team for their assistance and insight and the Stem Cell Network, Genome Prairie, and the Alberta Heritage Foundation for Medical Research for their research support.

2

Ibid., s. 10. This section provides that "[n]o person shall, except in accordance with the regulations and a licence, alter, manipulate or treat any human reproductive material for the purpose of creating an embryo."

The Bill's beginnings can be traced to recommendations made by the 1993 Royal Commission on New Reproductive Technologies. See Canada, Proceed with Care: Final Report of the Royal Commission on New Reproductive Technologies (Ottawa: Royal Commission on New Reproductive Technologies, 1993) [hereinafter Proceed with Care]. In 1996, the Government introduced Bill C47, An Act respecting human reproductive technologies and commercial transactions relating to human reproduction, 2d Sess., 35th Parl., 1996. This Bill, which was not unlike Bill C-56, died when the 1997 federal election was called. In May of 2001, the government released Canada. Proposal for Legislation Governing Assisted Human Reproduction: Drafi Legislation (Ottawa: Health Canada, 2001), online: Health Canada Online <www.hc-sc.gc.ca/english/reproduction/ legislation.pdi $>$ (date accessed: 30 June 2002). The hope was that the Proposal would stimulate public input. In addition, it set the framework for consultation and analysis by the Standing Committee on Health. From May until December 2001, the Standing Committee on Health heard testimony on the Proposal from a wide variety of individuals, including scientists, legal scholars, clinicians, ethicists, and public representatives. In December 2001, the Committee released the report Canada, Assisted Human Reproduction: Building Families (Ottawa: House of Commons Canada, 2001) (Chair: B. Brown), online: Standing Committee on Health <www.parl.gc.ca/ InfoComDoc/37/1/HEAL/Studies/Reports/healrp01-e.htm> (date accessed: 30 June 2002) [hereinafter Standing Committee on Health]. 
regulation of stem cell research and somatic cell nuclear transfer, ${ }^{5}$ nor those individuals from the anti-abortion community, for example, who favour more restrictions. ${ }^{6}$ In many respects, the Bill is a reasonable compromise. The government was subject to a variety of conflicting political pressures. Most notably, it was compelled to respond to the disappointing and poorly argued report of the Standing Committee on Health, released in December 2001, that called for, among other things, much tighter restrictions on stem cell research and the banning of human gene patents. ${ }^{7}$ As such, many in the academic community were left with the feeling that the Bill was not perfect, but certainly could have been much worse.

Nevertheless, I would suggest that the importance of the topic necessitates a further analysis of the proposed Bill, if only to inform future legislative activity. ${ }^{8}$ The primary objective of this comment is to provide further support for the position that a flexible regulatory approach should be adopted.

This comment begins with a brief analysis of the relevant data on public perceptions and opinions. Much of the debate about the Bill, and stem cell research in particular, has been characterized by a polarized presentation of the issues in the popular press those who view it as morally reprehensible against those who do not. Such portrayals of public opinion are overly simplistic and do little to inform the debate. In addition, despite all evidence to the contrary, inaccurate claims of broad social consensus continue to be used to justify many of the prohibitions. For these and other reasons, analyzing available data seems a valuable starting point. In the end, this comment suggests that absent compelling policy justifications, the nature and diversity of views associated with reproductive technologies make the use of statutory criminal bans difficult to support.

To further highlight the problems with the use of rigid prohibitions, I critique the decision to criminally ban therapeutic cloning. This critique is followed by a brief discussion of the narrow scope of the Bill. Again, the goal of both of these sections is

s The use of somatic cell nuclear transfer for non-reproductive purposes is often referred to as "therapeutic cloning." Though I feel this is an unfortunate term that has contributed to some of the confusion about the application of the technique, the term has made it into common usage and, as such, I will use the term "therapeutic cloning" in this Comment. See B. Vogelstein, B. Alberts \& K. Shine, "Please Don't Call it Cloning!" (2002) 295 Science 1237.

- Southam Newspapers, "Anti-abortion march focuses on stem cell bill" Edmonton Journal (11 May 2002) All.

7 Standing Committee on Health, supra note 4. A full critique of the Standing Committee on Health's report is beyond the scope of this paper. For a brief analysis, see T. Caulfield, "Canadian Reproductive Technology Law: A Step Backwards" Folio (25 January 2002) online: University of Alberta <www.ualberta.ca/publicas/folio/0102/0125/06.html> (date accessed: 15 July 2002). However, much of the Report appears to be based on a poor understanding of the relevant science and weak or incomplete ethical justifications. The inadequacies of the Report seem particularly stark when compared to more thoughtful policy documents, such as Cloning Californians? Report of the California Advisory Committee on Human Cloning (Sacramento: California Advisory Committee on Human Cloning, 2002), online: Stanford Law School <lawschool.stanford.edu/ library/special/cloning.californians.pdfs (date accessed: 15 July 2002).

8 In fact, even if the Bill passes, we may be revisiting these issues in three years. Section 70 states that the administration of the Bill is to be reviewed within three years after coming into force. 
to support the adoption of the regulatory Agency, as proposed in the Bill, and suggest that the government go one step further and place most, if not all, of the statutorily prohibited activities in the hands of the regulatory body.

\section{The Relevant Provisions of the Bill}

I will review three aspects of the Bill: the prohibited activities, the controlled activities, and the creation of a federal regulatory body.

Section 5 of the Bill contains most of the relevant prohibited procedures which include, ${ }^{9}$ inter alia, human reproductive cloning, the creation of an embryo for research purposes, ${ }^{10}$ germ line alterations, ${ }^{11}$ the creation of a chimera, ${ }^{12}$ and non-health related sex selection. ${ }^{13}$ In addition, because the Bill bans all forms of human cloning, it also bans "therapeutic cloning." 14

The Bill also establishes the Assisted Human Reproduction Agency of Canada, with the broad mandate to "(a) protect and promote the health and safety, and the human dignity and human rights, of Canadians, and (b) to foster the application of ethical principles" in relation to reproductive technologies." Is The Agency has powers to issue licences for a variety of "controlled activities," including, inter alia, the altering, manipulating, or treating of "any human reproductive material for the purpose of creating an embryo" or, by and large, any use of an in vitro embryo. ${ }^{16}$ The Bill also gives the Agency jurisdiction over any research involving an in vitro embryo, such as stem cell research that implicates the use of a human embryo. ${ }^{17}$

Few, if any, would argue that we should not carefully regulate all of these activities. However, the manner of and justifications for regulation in this context remain hotly contested issues.

Other activities prohibited by the Bill include payment for surrogacy (s. 6), the purchase of gametes and reproductive material (s. 7), the use of reproductive material without consent (s. 8), and the obtainment of gametes from a minor (s. 9).

Ibid., s. 5(1)(b) provides that "[n]o person shall knowingly create an in vitro embryo for any purpose other than creating a human being or improving or providing instruction in assisted reproductive procedures."

Ibid., s. $5(1)(f)$ provides that "[n]o person shall knowingly alter the genome of a cell of a human being or in vitro embryo such that the alteration is capable of being transmitted to descendants." Ibid., ss. 3 and 5(1)(i) provide that "[n]o person shall knowingly create, or transplant a chimera into either a human being or a non-human life form."

lbid., s. 5(1)(e).

Ibid., s. 3. "[H]uman clone means an embryo that, as a result of the manipulation of human reproductive material or an in vitro embryo, contains the same nuclear deoxyribonucleic acid sequence as is found in the cell of a living or deceased human being, fetus or other embryo."

Ibid., s. 22.

lbid., s. 10.

Ibid., s. 40(2) states that the Agency may issue a "license authorizing the use of an in vitro embryo for the purpose of research" but only if the "Agency is satisfied that the use is necessary for the purpose of the proposed research." 


\section{Public Support of Stem Cell Research}

Stem cell research is often portrayed as a topic that divides Canadian politicians. As soon as the Bill was introduced, there were calls for a free vote in order to allow all Members of Parliament to vote according to their personal views. ${ }^{18}$ Though a number of influential politicians clearly have entrenched opinions regarding the inappropriateness of research involving embryos, the focus on political positions has caused the broad public support of the research, and an appreciation of the depth and complexity of the moral and ethical concerns, to be lost from the national dialogue.

Indeed, I am unaware of any research that shows a strong public objection to ES cell research. Survey work by Environics in March of 2002 found that 76 percent of Canadians surveyed approve of ES cell research. ${ }^{19}$ A 2001 study found that 86 percent of respondents thought it acceptable to retrieve stem cells from donated embryos. ${ }^{20}$ Another study found that, even when explicitly asked about the moral acceptability of various sources of stem cells - such as bone marrow, umbilical cords and embryos most respondents rated human embryos as an acceptable source. ${ }^{21}$ Research in other jurisdictions has also found a high level of support. ${ }^{22} \mathrm{~A}$ study in the United States found that even among those with an identified religious affiliation, there was no strong objection to stem cell research - and given the high-profile nature of the abortion debate in that country, this data is surprising. In the study, it was found that responding Catholics ( 54 percent), Protestants ( 68 percent), and even those who view themselves as Evangelical (51 percent) support stem cell research. ${ }^{23}$

See, e.g., S. McCarthy, "Reproduction bill divides parties" Globe \& Mail (11 May 2002) A12.

1" "Three-Quarters of Canadians Surveyed Approve of Embryonic Stem Cell Research Using Spare Embryos," online: Juvenile Diabetes Research Foundation Press Releases <www.jdrf.ca/press/ index.htm> (last modified: 12 April 2002). The survey data was collected by Environics between 7-24 March 2002 and involved 2014 Canadians. The data reveals strong support of the use of spare embryos for stem cell research regardless of religious and federal political preference. Pollara Research and Earnscliffe Research and Communications, Public Opinion Research into Biotechnology Issues Fifth Wave (Ottawa: Biotechnology Assistant Deputy Coordinating Committee, Government of Canada, 2001) at 10. The researchers suggest that the Canadian public has "a surprising level of awareness" of stem cells and the relevant issues. In focus groups, it was found that "about a quarter of participants had a real sense of what was involved and why the area had become controversial - again, a surprising level of engagement." Interestingly, it was also noted that many focus-group participants "assume embryos are aborted fetuses (raising negative views about use of their tissue) unless it is made explicit that they are weeks-old frozen products of in-vitro fertilization that were to be discarded in any case (in which circumstances there is no barrier to their use)." A recent national survey by Canadian Press/Leger Marketing, How Canadians Perceive Human Cloning (Montreal: Canadian Press/Leger Marketing, 2001), online: Leger Marketing <www.legermarketing.com/english/set/html> (date accessed: 16 July 2002) suggests that 55.4 percent of Canadians support the cloning of embryos, while only 3.7 percent had no knowledge of this application of the technology.

$\because \quad$ Pollara Research, Benchmark Survey on Awareness and Knowledge Levels of Assisted Human Reproduction (Ottawa: Health Canada, 2001).

$\because \quad$ See, e.g., The Wellcome Trust, Public Perspectives on Human Cloning (Great Britain: The Wellcome Trust, 1998), online: The Wellcome Trust <www.wellcome.ac.uk/en/images/cloning report_slimversion_2816.pdf $>$ (date accessed: 16 July 2002).

"ABCNews/Beliefnet Poll, "The Surprising Politics of Stem Cells" online: Beliefnet <www. beliefnet.com/story/82/story_8276_1.html> (date accessed: 28 June 2002). 
Some may argue that this public support of ES cell research is built on the tremendous "hype" that has surrounded stem cells since their discovery in $1998 .{ }^{24}$ That is, the public supports stem cell research because they believe, inappropriately, that therapeutic benefits are a near-future possibility. There is no doubt that stem cell research, and biotechnology in general, ${ }^{25}$ have received a significant amount of media attention and that much of the coverage may give an overly optimistic impression. ${ }^{26}$ This is a legitimate point of view and we should be cautious not to devise policy based on unrealistic expectations of benefit. However, many of the "hyped" potential benefits, such as the production of organs for transplantation, are not without foundation, though the possible realization of such benefits is decades - and not years - away. As such, it is appropriate for the public to at least consider these hypothetical benefits in their assessment of the technology (just as they should consider possible, but not established, risks).

Moreover, it should not be forgotten that, rightly or not, the Canadian public is generally very supportive of scientific research, ${ }^{27}$ even if it is removed from immediate benefit. Even in the United Kingdom, where there has been a higher level of "science controversy," a study found that 72 percent of those surveyed agree that "[e]ven if it

J.A. Thomson et al., "Embryonic Stem Cell Lines Derived from Human Blastocysts" (1998) 282 Science 1145; D. Butler, "Breakthrough Stirs US Embryo Debate" (1998) 396 Nature 104; P. Cohen, "Organs Without Donors" New Scientist (11 July 1998) 4; E. Marshall, "Claim of HumanCow Embryo Greeted with Skepticism" (1998) 282 Science 1390. See generally T. Caulfield, "Underwhelmed: Hyperbole, Regulatory Policy and the Genetic Revolution" (2000) 45 McGill L.J. 437.

$\therefore \quad$ See, e.g., J. McCartney, "Embryonic Stem Cell Research and Respect for Human Life: Philosophical and Legal Reflections" (2002) 65 Alb. L. Rev. 587 at 623: "Stem cell research in general, and embryonic stem cell research specifically, is in the very early stages of development, and it is unlikely, despite claims to the contrary, that stem cells will prove to be 'magic bullets' that will quickly remedy all of humanity's ills."

See also HarrisInteractive, "The Public is Overwhelmingly Optimistic and Supportive of Genomics Research - However, Knowledge and Understanding Remain Modest" (2001) I Health Care News 1, online: HarrisInteractive <www.harrisinteractive.com/news/newsletters/healthnews/ HI_HealthCareNews2001voll_iss20.pdf> (date accessed: 16 July 2002). See also E. Einsiedel, Public Perceptions, Media Coverage and Public Policy (Calgary: University of Calgary, 1997). in which it is suggested that Canadians have a generally more positive outlook on biotechnology than those in the European Community but also appear to be far more selective about the applications they support. Other European research has found a degree of ambivalence regarding biotechnology in general (INRA (Europe) - ECOSA, Eurobarometer 52.1: The Europeans and Biotechnology, online: Eurobarometer Special Surveys <europa.eu.int/comm/public_opinion/ archives/special.htm> (last modified: 15 March 1998)). However, support increases when the technology is viewed as having some socially beneficial application (e.g., genetic testing and GM bacteria to eat oil spills). A variety of other studies have found a similar utilitarian analysis of biotechnology. See, e.g., U. Frewer, C. Howard \& R. Shepherd, "Public Concerns in the United Kingdom about General and Specific Applications of Genetic Enginecring: Risk. Benefit and Ethics" (1997) 22 Sci. Tech. Human Values 98; and J. Hampel. U. Pfenning \& H. Peters. "Attitudes Towards Genetic Engineering" (2000) 19 New Genetics \& Soc. 233. Again, the role of "hype" in relation to these attitudes deserves consideration. 
brings no immediate benefits, scientific research which advances the frontiers of knowledge is necessary and should be supported by the Government."28

Finally, policy-makers and commentators need to be careful about how they characterize the role of "ethical/moral" issues in the formation of public opinion. ${ }^{29}$ There is no doubt that moral belief is highly relevant in this context. ${ }^{30}$ And for some Canadians, it is undoubtedly a dominant consideration. However, for most, the role of moral beliefs in the formation of attitudes toward a given technology appears to be a tremendously complex process. It involves, among other things, a weighing of benefits against risks, a consideration of the degree to which a given personal belief should be imposed on society generally, and the degree to which the relevant regulators can be trusted. This process appears to have led the majority of Canadians to support embryonic stem cell research. However, the nature and depth of the relevant moral beliefs undoubtedly varies greatly. ${ }^{31} \mathrm{~A}$ national consensus based on moral beliefs will, in all likelihood, remain unattainable. ${ }^{32}$

Interestingly, there is some evidence that for most Canadians, ethical/moral concerns are ranked far behind other considerations. For example, in one study, Canadians were asked to choose the most important concerns impacting their assessment of a given genetic technology. Long-term risks to health were considered the most important (69 percent) and "ethical concerns" the least ( 8 percent) ${ }^{33}$ Similarly, it was found that most Canadians thought decisions about biotechnology should be based mainly on scientific evidence ( 58 percent) rather than on "moral and ethical issues." 34

Canada should not craft laws based on opinion polls. They are, for instance, an inherently limited methodology (for example, much can depend on how the questions are asked). ${ }^{35}$ Nor am I saying that the opinions of the vocal minority (about one in five Canadians in the case of ES cell research) should be ignored in the development

Wellcome Trust, Science and the Public: A Review of Science Communication and Public Attitudes to Science in Britain (Wellcome Trust: Office of Science and Technology, 2000) at 22, online: Wellcome Trust <www.wellcome.ac.uk/en/images/sciencepublic_3391.pdf>.

See infra, note 45. See also P. Manning, "Canada's Test of Faith" Globe \& Mail (4 May 2002) A15; P. Manning, "We're Hatching a Flawed Bill" Globe \& Mail (27 May 2002) A13; and M. Valpy, "Church and State" Globe \& Mail (15 May 2002) A9. Frewer et al., supra note 27. See E. Einsiedel, Biotechnology and the Canadian Public: 1997 and 2000 (Calgary: University of Calgary, 2000) at 14.

3 Reproductive cloning is the only prohibited activity that is associated with clear evidence of a social consensus favouring a prohibition. See, e.g., the Wellcome Trust, supra note 22. See also D. Swift, "Send in the Clones?" (1999) 35 Medical Post 38. Interestingly, a poll of Canadian physicians done by the Medical Post found "a surprisingly high number, one in five doctors (19\%), ... approve of propagating entire human beings by cloning." Pollara/Earnscliffe, supra note 20.

4 Ibid.

is For a general discussion of the performance and analysis of public-opinion surveys, see E. Babbie, The Practice of Social Research, 9th ed. (Belmont: Wadsworth, 2001). 
of a regulatory regime. ${ }^{36}$ However, the data on public opinion are important for a number of reasons.

First, policy-makers should not justify personal positions based on a non-existent public consensus and must recognize that a call for a more restrictive research environment is counter to the current public ethos. The calls for tighter restrictions of stem cell research and therapeutic cloning are often justified, implicitly or explicitly, ${ }^{37}$ by appeal to social consensus. But this consensus clearly does not exit.

This is not to say that strictly moral/ethical arguments against a particular technology could not support a prohibition - even in the face of a promotive or ambivalent public. Some of the most important legal reforms, such as the human rights movement in the United States, have faced a degree of public opposition. Moreover, there are many examples of laws being passed without strong public support. ${ }^{38}$ But without a clear and consistent public mandate, it is essential that the philosophical foundations for a particular regulatory response be clearly articulated and have an enduring relevance. This is especially true in the regulation of science, where so many of the relevant variables - considerations of safety, the state of the science, and public opinion - are in a state of flux. Compelling policy justifications remain absent for many of the prohibited activities, as I will argue below in relation to therapeutic cloning.

The available public opinion data also hurts the "intuitive ethics" rationale for prohibitions. A number of commentators have suggested that prohibitions can be justified solely by reference to the sense of moral repugnance invoked by a variety of the technologies. ${ }^{39}$ However, given the available public opinion data, one wonders whose "repugnance" we are being asked to respect? Should we base our regulatory policy on the intuitive response of a minority of Canadians?

The second reason this opinion data is relevant is that it supports the use of the regulatory Agency. Indeed, without a strong public mandate against, for example, ES cell research, or a unified "moral" position, it seems entirely appropriate for the government to give the Agency a broad regulatory mandate. ${ }^{40}$ The Agency will have

See Pollara/Earnscliffe, supra note 20 at 10 , where the authors summarize the existing data as follows: "Most Canadians (about $70 \%$ ) say they find stem cell research acceptable with a determined minority (about 1 in 5) finding it totally unacceptable."

37

(o such justifications, see Caulfield, infra note 41 at $338-41$.

See C. Condit, "What is 'public opinion' about genetics?" (2001) 2 Nature Rev. Genet. 811.

See L.R. Kass, "The Wisdom of Repugnance" (1997) 216 New Republic 17; M. Midgely, "Biotechnology and Monstrosity - Why We Would Pay Attention to the 'Yuk Factor" (2000) 30 Hastings Ctr. Rep. 7; M. Somerville, The Ethical Canary: Science, Society and the Human Spirit (Toronto: Viking, 2000). For a more complete critique of the role of intuitive ethics in regulatory policy, see T. Caulfield, L. Knowles \& E.M. Meslin, "Law and Policy in the Era of Reproductive Genetics" [forthcoming].

4) Indeed, there is some evidence suggesting that the Canadian public views "regulation," rather than specific bans, as the preferred regulatory approach. See Pollara Research, supra note 21, where it was found that in 2001,59 percent of the respondents thought research on embryos should be regulated, 26 percent thought it should be banned and 12 percent thought it should be neither banned nor regulated. 
the flexibility necessary to respond to diverse and changing social attitudes. ${ }^{41}$ And, hopefully, the Agency can serve as a forum for ongoing public dialogue. Legislated bans, on the other hand, imply a closure of the public debate.

\section{The Ban on "Therapeutic Cloning"}

To further explore the benefits of the regulatory approach, I will now consider the proposed ban on therapeutic cloning. ${ }^{42}$

Therapeutic cloning is a technique which, it is hoped, will one day allow the creation of tissue that has the same DNA as an individual in need of a transplant. Though still highly theoretical, the process would likely involve taking a nucleus from the cell of an individual in need of a transplant, such as an individual with diabetes seeking pancreatic islets. The nucleus would then be transplanted into an ovum. The ovum would be stimulated to facilitate cell division and stem cells would be removed from the "embryo." The stem cells would be used to "grow" whatever tissue is needed, such as new pancreatic islets. Because the new tissue would have the same genetic makeup as the transplant recipient, the chance of rejection would be reduced or eliminated.

The decision to statutorily ban therapeutic cloning was not a surprise. Last year's proposed legislation contained a ban on therapeutic cloning, and the Report of the Standing Committee on Health also recommended a prohibition. However, as I have noted several times elsewhere, ${ }^{43}$ the justifications for the ban are so weak that one is left wondering what the real motivation is. ${ }^{44}$

Despite evidence to the contrary, social consensus remains one of the primary justifications for the use of criminal bans. For example, the Standing Committee on Health justifies the use of criminal prohibition based largely on social consensus.

An outright statutory ban signals more clearly that certain activities are either unsafe or socially unacceptable. The use of the statutory ban also signals that these activities are of such concern to

"I have discussed the limitations of criminal law elsewhere. See T. Caulfield, "Clones, Controversy, and Criminal Law: A Comment on the Proposal for Legislation Governing Assisted Human Reproduction" (2001) 39 Alta. L. Rev. 335. See also S. Anand's Response to that paper, along with my Rejoinder, at 493 and 507 of this issue.

42 In this section, I draw on the work done with my colleagues Abdallah Daar, Peter Singer \& Bartha Maria Knoppers, for a co-authored editorial: A. Daar et al., "Ban cloning, not its life-saving cousin" Globe \& Mail (9 May 2002) A21.

4.3 Ibid. See also Caulfield, supra note 7.

44 In the United States, Christian perspectives have played a significant role in the development of policy in this area. See, e.g., C. Donley Young, "A Comparative Look at the U.S. and British Approaches to Stem Cell Research" (2002) 65 Alb. L. Rev. 831 at 854, wherein it is stated that "Religious influences also play a part in the regulation of stem cell research. In the United States, religion is a pervasive factor in many of our laws - examples include prohibitions of and limitations on the use of contraceptives, same-sex marriages, and abortion." Though the role of the Christian perspective has been less explicit in Canada, given the absence of other rationales, one is left with the impression that it is beginning to have a major political influence. 
Canadians that their status as a prohibited activity may not be altered except with the approval of Parliament. ${ }^{45}$

But is there evidence that therapeutic cloning is a grave concern to Canadians? On the contrary, available data suggests that the public supports the idea of therapeutic cloning. ${ }^{46}$ In fact, other than within the anti-abortion community, it is difficult to find any sector of society that clearly endorses a ban. There is no unified religious perspective ${ }^{47}$ the process continues to be endorsed by numerous respected scientific entities and policy-making bodies, ${ }^{48}$ and while ethical and legal scholars have long debated the moral concerns associated with this process, ${ }^{49}$ the academic community is also far from a consensus. ${ }^{50}$

I am not arguing that the broad diversity of views and lack of social consensus means that the government should not tightly regulate therapeutic cloning. Rather, this lack of consensus makes it tremendously difficult to support a ban based on the claim that the technology is clearly "socially unacceptable."si

After the fallacious "social consensus" argument, safety and concerns regarding the commodification of human reproductive material are the two most commonly used explicit justifications for a ban on reproductive cloning. ${ }^{52}$ But, again, these two

Standing Committee on Health. supra note 4 at 9.

Caulfield, supra note 41 at 337.

See, e.g., C. Abraham, "Stem-Cell Study to Begin Soon in Saudi Arabia" Globe \& Mail (13 June 2002) A7, where it is reported that Islamic scholars are drafting "religious rules, or fatwas, to guide the world's one billion Muslims through this new frontier in medicine." It is anticipated that the new fatwas "will eventually approve the use of so-called therapeutic cloning as a life-saving treatment." See also, ABCNews/Beliefnet Poll, supra note 23. There is division even within the religious right in the United States - as exemplified by the recent endorsement provided by "two right-to-life conservatives, senators Orrin Hatch (R-UT) and Strom Thurmond (R-SC)." C. Holden. "Hatch Signs On to Pro-Research Bill" (2002) 296 Science 997.

* See, e.g., the California Advisory Committee on Human Cloning, supra note 7, recommendation 2: "The Committee unanimously agrees that California should not prohibit but should reasonably regulate human non-reproductive cloning. We believe that use of this technology offers potential medical and scientific benefits while not raising many of the same concerns as human reproductive cloning." See also "US Should Back Research Cloning" Opinion (2002) 417 Nature 103; BBC News, "Lords Back Cloning Research," online: BBC News <news.bbc.co.uk/hi/ english/sci/tech/newsid_1843000/1843368.stm> (last modified: 27 February 2002).

See, e.g., McCartney, supra note 26.

In fact, some have gone so far as to suggest that. from an ethical perspective. the production of ES cells through therapeutic cloning is preferable to the use of surplus IVF embryos. J.E.S. Hansen, "Embryonic Stem Cell Production Through Therapeutic Cloning Has Fewer Ethical Problems Than Stem Cell Harvest From Surplus IVF Embryos" (2002) 28 J. Med. Ethics 86. See Health Canada documentation provided with the Proposed Legislation in May 2001, where it is stated that "There is broad consensus that the activities that would be banned under the proposed legislation are not acceptable in Canada." Health Canada, "Assisted Human Reproduction: Frequently Asked Questions," online: Health Canada <www.hc-sc.gc.ca/english/ archives/releases/2001_44ebk3.htm> (date accessed: 30 June 2002).

See Standing Committee on Health, supra note 4 at 10: "[T]herapeutic cloning should be banned as it is unsafe and commodifies the embryo." Though the slippery-slope argument is rarely used by Canadian policy-makers in this context, it is commonly heard in the debate in the United States. See, e.g., L.R. Kass, "Why We Should Ban Human Cloning Now: Preventing a Brave New 
concerns are hardly rationales for a statutory criminal ban. It is unclear what unique safety concerns are associated with therapeutic cloning (indeed, there is no official documentation regarding the issue). To my knowledge, therapeutic cloning would be no more dangerous than many other experimental treatments. In addition, it would be unusual for the government to develop a specific statutory ban for a potentially unsafe medical procedure - regulation, both through the health professions and Health Canada, is the norm.

The concern regarding the potential commodification of human reproductive material, and ova in particular, is completely legitimate. Research into therapeutic cloning will need to use human eggs. This has the potential to heighten the market for ova. However, just as we have banned the buying and selling of human kidneys but not kidney transplants, we should ban the buying and selling of human eggs but not the potentially therapeutic process.

Finally, the scientific uncertainty surrounding therapeutic cloning is often used to support the proposed ban. ${ }^{53}$ It is true that the scientific feasibility and therapeutic value of the procedure remain unclear. ${ }^{54}$ However, this is hardly a justification for a ban (should we also ban cold fusion?). Yes, the scientific legitimacy needs to be considered in the ethical evaluation of a given technology or research protocol, ${ }^{55}$ but we do not ban things just because they may not work.

World," online: The New Republic Online <www.tnr.com/052101/kass052101_print.html> (last modified: 21 May 2001). The concern is that research on therapeutic cloning will make reproductive cloning more likely. This seems a reasonable argument for regulation, but not for a ban. Governments rarely, if ever, ban "precursor" research or technologies. For example, we allow research on highly dangerous chemicals, radioactive materials and infectious agents, all of which, if used improperly, pose a far greater immediate threat to humans than cloning technology.

See Standing Committee on Health, ibid., in relation to the uncertainties associated with ES cell research. A related argument often associated with therapeutic cloning, and stem cell research in general, is that we, as a society, focus far too many resources on "bio-medical" technology. I have great sympathy for this concern. But again, should we use criminal bans to effectuate this kind of social change? If so desired, a regulatory body would be much better placed to consider the shifting socio-political environment.

${ }^{54}$ However, this uncertainty is beginning to dissipate. See, e.g., H. Auchincloss \& J. Bonventre, "Transplainting Cloned Cells into Therapeutic Promise" (2002) 20 Nature Biotechnology 665; P. Cohen, "Therapeutic cloning, 'proof of principle," online: NewScientist.com <www.newscientist.com/hottopics/cloning/cloning.jsp?id=ns99992356> (last modified: 2 June 2002), where it is reported that a "key hypothetical benefit of therapeutic cloning has been demonstrated in practice for the first time. The new experiments show that the technology can prevent the immune rejection of transplanted tissue." In addition, it should be noted that at least some stem cell researchers believe that the true value of therapeutic cloning has, in fact, been underplayed. See, e.g., "Reasons to be Cloned" Editorial (2001) 414 Nature 567 where it is noted that therapeutic cloning may also have a variety of research applications: "For example, one way to study a disease such as Parkinson's at a molecular level would be to set up ES-cell lines from a patient and from controls, grow them into large quantities of dopaminergic neurons in Petri dishes, and find out why the patient's cells die."

ss MRC, NSERC and SSHRC, Tri-Council Policy Statement: Ethical Conduct for Research Involving Humans (Ottawa: Medical Research Council of Canada, 1998), online: <www.nserc.ca/programs/ ethics/english/policy.htm> (date accessed: 16 July 2002). 
In total, the lack of social consensus, the shifting nature of the relevant science and the absence of concrete and coherent ethical counter-arguments, make therapeutic cloning a wonderful example of a technology that should be closely regulated rather than banned.

\section{SCOPE OF THE BILL}

The scope of the Bill also deserves comment. The Bill is explicitly restricted to topics associated with reproductive technologies. In general, this means that, on the face, it only addresses research that involves human gametes or embryos. While one can sympathize with the government's desire to place clear boundaries on the scope of the Bill and the activities of the Agency, this demarcation means that the legislation and Agency may not have jurisdiction over activities that are very closely related, scientifically and ethically, to a number of controlled and prohibited activities.

Chimeras, for instance, are defined as "[human] embryo[s] into which a cell of any non-human life form has been introduced or [human] embryo[s] that [consist] of cells of more than one embryo, fetus or human being." $\$ 66$ The creation of a "chimera" is prohibited by s. $5(1)(i){ }^{57}$ However, most of the current and probable future research with chimeras will involve the grafting of human ES cells into non-human blastocysts, fetuses and adult tissue. The grafting of non-human ES cells into human embryos is not a likely or even an especially scientifically valuable manner in which to create a chimera. ${ }^{58}$ The Bill's definition is, from a scientific perspective, tremendously narrow. The Bill, therefore, is not relevant to the vast majority of stem cell research involving chimeras. ${ }^{59}$

Indeed, given the stark difference between the scientific understanding of chimeras and the definition in the Bill, and the clear intention of the Bill to focus on reproductive material, one is left with the impression that the Bill is not intended to capture work with non-section 5(1)(i) chimeras. ${ }^{60}$ However, chimeras created with human ES cells and non-human tissue, such as mouse blastocysts, also create numerous unique policy

The Bill, supra note 1 at s. 3.

Ibid., s. 5(1)(i): "No person shall knowingly create, or transplant a chimera into either a human being or a non-human life form."

I am grateful to all the participants of the Stem Cell Network, NCE, Chimera Workshop, Montreal, 13 June 2001, and the Workshop Chair, Francoise Baylis, for the clarification of the issues relevant to chimeras in this context.

sy It is interesting to note that s. II of the Bill, which deals with "transgenics," has, at least, the potential to capture some chimeric work. The section states that researchers will need to have a licence to do work that combines "any part or any portion of the human genome specified in the regulations with any part of the genome of a species specified in the regulations." Supra note 1 at s. 11(1). Though the interaction of genomes in chimeric research is highly unlikely, it is possible. However, "it wouldn't happen in a predictable or purposeful way," according to Dr. J. Cross, Professor of Biochemistry, University of Calgary (personal communication, 31 July 2002). For example, the Agency would certainly oversee chimeric work that involved the derivation of new stem cells from an in vitro embryo (see s. 40(2)), but will the Agency be involved in the regulation of research involving an existing stem cell line and a non-human blastocyst or fetus? 
concerns. ${ }^{61}$ The fact that the Government has criminally banned one type of chimera but left all others unregulated creates an odd contrast. What are the justifications for this approach? ?2 $^{62}$ Many of the prohibitions are justified in the documentation that accompanied the Proposal for Legislation, or addressed in the Standing Committee on Health. However, I am unaware of any formal documentation that explains the government's position on chimeras.

The proposed regulatory scheme would also not cover stem cell research that involves tissue from human fetuses. Human stem cell lines are usually derived from "surplus" embryos, left over from the process of in vitro fertilization. However, stem cells can also be obtained from aborted fetuses. Again, why tightly regulate one type of research and ignore the other?

Unless the government can provide a more compelling rationale than the production of a convenient regulatory boundary, I believe strongly that the Agency needs to have broad discretion to handle issues closely related to its general mandate - such as research involving chimeras and human fetal material. Restricting the application of the regulatory framework to reproductive issues creates an artificially narrow area of jurisdiction - a problem that was faced by the Royal Commission on New Reproductive Technologies. ${ }^{63}$ In the end, that Commission recognized that it could not restrict itself to traditional reproductive issues alone. ${ }^{64}$ Increasingly, in an age when science moves forward at an incredible pace and in unpredictable directions, it would be a missed opportunity not to create a regulatory scheme capable of handling a wide variety of ethical and scientific concerns.

\section{Concluding Thoughts}

This brief comment is far from a comprehensive analysis of the issues associated with Bill C-56. The primary goal was to provide further support for the use of a flexible regulatory approach - an approach that Bill C-56 partially adopts. However,

"1 Canadian Institutes for Health Research, "Ethics in CIHR: Human Pluripotent Stem Cell Research: Guidelines for CIHR-Funded Research," online: CIHR Canada <www.cihr-irsc.gc.ca/publications/ ethics/stem_cell/stem_cell_guidelines_e.shtml> (last modified: 17 May 2002); see also J.S. Robert \& F. Baylis, "Scientific and Moral Confusion about Species Identity" [forthcoming].

6.2 Proceed with Care, supra note 4.

6.3 Ibid.

$\omega \quad$ lbid. at 3-4. The Commission's stated mandate is to undertake an inquiry and produce a report on "current and potential medical and scientific developments related to new reproductive technologies, considering in particular their social, ethical, health, research, legal and economic implications and the public interest, recommending what policies and safeguards should be applied." The Commission considered, among others, the broad issues of commercialization and intellectual property, ownership and transfer of human tissue, legal rights and status of persons impacted by reproductive technologies and the scientific development of the field of "reproductive technologies." The Commission realized that "the questions embraced by the Commission's mandate [could not] be considered in isolation from one another, for they are interdependent at several levels, and decisions about one often have repercussions for another - hence the need for a comprehensive, multidisciplinary approach to our task and a comprehensive public policy response." 
I believe that the diversity of public attitudes and values and the nature of the science and related ethical concerns warrant a more complete adoption of the regulatory scheme. ${ }^{65}$

is I am not the first or only commentator to advocate this broad, flexible regulatory approach. Indeed.

it seems to be the preferred option within the legal-academic community. See, e.g. L. Knowles, "Science Policy and the Law: Reproductive and Therapeutic Cloning" (2001) 4 N.Y.U.J. Leg. \& Pub. Pol'y 13 at 20:

[I]t seems clear that rather than using the law to react in an ad hoc manner to specific scientific innovations, we should attain a more comprehensive understanding of new developments, and draft laws that reflect that understanding. It is possible to develop a broadly framed legislative mandate and to structure regulatory bodies that are responsive to change.

See also K. Venturatos Lorio, "The Process of Regulating Assisted Reproductive Technologies: What We Can Learn From Our Neighbors — What Translates and What Does Not" (1999) 45 Loy. L. Rev. 247; M. Herder, "The UK Model: Setting the Standard for Embryonic Stem Cell Research?” (2001) 10 Health L. Rev. 14. 